\title{
Leaf development and dry matter production of subterranean clover cultivars in relation to autumn sward management
}

\author{
D.J. MOOT, A.D. BLACK, W.R. SCOTT, AND J. RICHARDON \\ Soil, Plant and Ecological Sciences Division, P.O. Box 84, Lincoln University, Canterbury \\ moot@lincoln.ac.nz
}

\begin{abstract}
Seeds of five cultivars of subterranean clover, together with one of white clover, were sown in a wide range of temperature regimes under both controlled environment and field conditions. Results were consistent across temperature regimes and showed that the first trifoliate leaf emerged after $230{ }^{\circ} \mathrm{Cd}$ for all subterranean clover cultivars and $309^{\circ} \mathrm{Cd}$ for the white clover cultivar. For subterranean clover, exponential leaf appearance commenced after $434{ }^{\circ} \mathrm{Cd}$ at the six total leaf stage. At this time, subterranean clover can be defoliated without causing permanent physical damage to seedlings. The field study at Lincoln University showed that subterranean clover that germinated in March produced $44 \mathrm{~kg} \mathrm{DM} / \mathrm{ha} /$ day for 158 days to yield approximately $7000 \mathrm{~kg} \mathrm{DM} /$ ha by mid-September. Subterranean clover that germinated in May produced $15 \mathrm{~kg} \mathrm{DM} / \mathrm{ha} /$ day for 120 days to yield only $1800 \mathrm{~kg}$ $\mathrm{DM} / \mathrm{ha}$ by mid September. These results are discussed in relation to the time of autumn grazing management for subterranean clover, including extrapolation to other climatic areas of New Zealand.
\end{abstract}

Key words: herbage yield, phyllochron, seedling establishment, thermal time, Trifolium subterraneum, T. repens, white clover

\section{Introduction}

Subterranean clover (Trifolium subterraneum) is a winter annual legume adapted to Mediterranean-type climates with warm mild winters and hot dry summers. The ultimate success or failure of the species depends on the number of seedlings that establish each autumn. Estimates of threshold seed reserves in the soil for the success of subterranean clover range from 200-600 kg/ha (Rossiter 1966; Carter \& Cochrane 1985; Dear et al. 1993). Allowing for the effects of seed dormancy, hardseededness and seed destruction by pests and diseases, Smetham (2003) calculated that the minimum amounts of seed required were 127,108 and $82 \mathrm{~kg} /$ ha for early-, mid- and lateflowering cultivars, respectively.
In areas of New Zealand where subterranean clover grows, the timing of the autumn rains required for germination is extremely variable, and may range from January to May. Following germination, it is generally accepted that subterranean clover pastures should be spelled until the seedlings are sufficiently well developed to survive grazing. Thomas (2003) indicated that the growing points of subterranean clover are pulled closer to the soil surface as the seedlings develop, conferring protection from grazing. However, no consistent criteria are available to define when the first grazing should occur in different sites or seasons.

As temperatures decline markedly between January and May, it is likely that the chronological time required (in days) for seedlings to reach a critical size will increase accordingly. However, as the chronological time requirement varies with season, its practical use in assisting decisions on grazing management is limited. Black et al. (2002) showed that, providing moisture is adequate, seedling leaf appearance is driven by the accumulation of thermal time (Tt) or degree-days $\left({ }^{\circ} \mathrm{Cd}\right)$. Specifically, the $\mathrm{Tt}$ required for the initiation of branch structures (stolons, runners or tillers) in seedlings has been identified as a key physiological parameter determining the successful establishment of pasture species. This criterion can assist management decisions on time of sowing and compatibility of species within a seed mixture. The same approach could also be used to assist guidelines for autumn grazing of subterranean clover.

Thus, the objective of this research was to quantify the $\mathrm{Tt}$ requirements for key development stages (first trifoliate leaf appearance, branch development, phyllochron) of subterranean clover seedlings using a combination of controlled environment and field experiments. The objective of the field experiment was to examine whether the results obtained in controlled environments could be replicated under field conditions. There were five cultivars of subterranean clover examined in this study. White 
clover (T. repens) was also included, both as a reference point (to compare with other studies in the literature), and because it is the most common pasture legume used in New Zealand.

\section{Materials and methods}

\section{Controlled environments}

A series of six controlled environment experiments was conducted. Each experiment was a randomised complete block design consisting of several clover cultivars with three replicates, but each experiment was conducted at a different nominal temperature (Table 1). For split temperatures, a $12 \mathrm{~h} / 12 \mathrm{~h}$ temperature regime was used.

Table 1 Subterranean and white clover cultivars and temperature regimes used for the six controlled environment experiments at Lincoln University.

\begin{tabular}{lcc}
\hline $\begin{array}{l}\text { Cabinet } \\
\text { experiment } \\
\text { number }\end{array}$ & $\begin{array}{c}\text { Nominal temperature } \\
\left({ }^{\circ} \mathrm{C} \text {, day/night }\right)\end{array}$ & Cultivars $^{1}$ \\
\hline 1 & 6 & $\begin{array}{c}\text { Demand, Denmark } \\
2\end{array}$ \\
3 & 18 & $\begin{array}{c}\text { Demand, Campeda, Denmark, } \\
\text { Goulburn, Leura, Woogenellup }\end{array}$ \\
4 & $16 / 8$ & $\begin{array}{l}\text { Demand, Campeda, Denmark, } \\
\text { Goulburn, Leura, Woogenellup }\end{array}$ \\
5 & $25 / 15$ & $\begin{array}{l}\text { Demand, Campeda, Denmark, } \\
\text { Goulburn, Leura, Woogenellup }\end{array}$ \\
6 & 25 & $\begin{array}{l}\text { Demand, Denmark, Campeda, } \\
\text { Goulburn, Leura, Woogenellup }\end{array}$ \\
\hline
\end{tabular}

\footnotetext{
1 'Demand' is a white clover (Trifolium repens). All other cultivars were $T$. subterraneum ssp subterraneum.
}

'Demand' white clover was included in all experiments, while all other clovers were subterranean clover ssp subterraneum. Plastic pots $0.37 \mathrm{~m}$ in diameter and $0.30 \mathrm{~m}$ deep were filled with 3-4 month potting mix. Each plot was designated as $358 \mathrm{~cm}^{2}$, one third of the total area of the pot, and sown with 50 viable inoculated seeds/plot.

Immediately after sowing, all pots were watered and placed in a controlled environment cabinet at the designated temperature for an $8 \mathrm{~h} / 8 \mathrm{~h}$ day/night photoperiod with a $4 \mathrm{~h}$ transition period at either end. Light reaching the leaf canopies had a photosynthetic photon flux density of $350 \pm 50 \mu \mathrm{mol} / \mathrm{m}^{2} / \mathrm{s}$ and relative humidity was maintained at $65 \%$. Plants were watered as required based on pot weight, and shifted daily to minimise edge effects.

Actual temperatures were monitored by inserting four temperature probes into each of three pots, with one probe (covered with aluminium foil) being placed $10 \mathrm{~mm}$ above ground and the other three $10 \mathrm{~mm}$ below the soil surface. Such placement has been recommended for accurate prediction of leaf appearance rates in crops (Peacock 1975; Jamieson et al. 1995). Temperatures were recorded every 2 minutes and integrated every 30 minutes with a HOBO data logger to determine mean daily temperatures. Due to small variations between nominal temperature settings and the soil surface temperatures the plants experienced, we used the latter for all analyses.

Seedlings were repeatedly thinned before they touched each other to avoid competition. Final populations were 16 plants/plot, and within this population, three plants/plot were marked with coloured wires for detailed monitoring.

\section{Field experiment}

A randomised split-plot design was sown in four replicates with 7 March (SD1), 21 March (SD2), 11 April (SD3) and 7 May (SD4) 2003 as the sowing dates for main plots, designed to span the expected range of timing of autumn rainfall. Sub-plot treatments were 'Denmark', 'Campeda', 'Goulburn', 'Leura' and 'Woogenellup' subterranean clovers and 'Demand' white clover sown in $1.0 \times 1.0 \mathrm{~m}$ plots.

The experiment was conducted in Iversen Field at Lincoln University on a Templeton silt loam soil, which was cultivated to produce a fine, firm seedbed using conventional methods. During cultivation, $200 \mathrm{~kg} / \mathrm{ha}$ of superphosphate $(9 \% \mathrm{P}, 12 \% \mathrm{~S})$ was incorporated to correct nutrient deficiencies indicated by a soil test.

Inoculated seed was broadcast at a range calculated to sow 2000 viable seeds $/ \mathrm{m}^{2}$ based on germination tests and thousand seed weights. Seeds were raked in and the experimental area kept moist using a garden sprinkler as required for the first sowing date. Significant rainfall (30 mm) on 28 March 2003 ensured 
seeds from all other sowing dates were sown into moist soil.

Soil temperature was recorded at $5 \mathrm{~mm}$ depth, every 2 minutes, and integrated every 30 minutes with a HOBO data logger to determine daily mean temperatures. All plots were hand weeded when necessary. Three plants in each sub-plot were marked with coloured wires for detailed monitoring.

\section{Measurements}

The number of emerged leaves on the monitor plants was counted daily until individual white clover plants had produced five leaves. Leaves were considered emerged as soon as the petiole was visible. The initiation of a stolon or runner in white and subterranean clovers, respectively, which emerge in the axils of main stem (MS) leaves, was also recorded. A stolon or runner was defined as initiated when one leaf had emerged on that axillary bud (Black et al. 2002).

Dry matter (DM) production was determined from one $0.2 \mathrm{~m}^{2}$ quadrat cut to ground level in each subplot at approximately monthly intervals. Actual harvest dates were 13 May, 18 June, and 7 August, with the final cut on 11 September 2003. Herbage was dried to constant weight at $70{ }^{\circ} \mathrm{C}$.

\section{Data analysis}

Data for each species were plotted as the reciprocal of the duration (in days) to the appearance of the first trifoliate leaf (MS leaf two) or the initiation of stolon or runner structures against the mean temperature. The inverse of duration (1/days) represents the development rate (Moot et al. 2000). A linear relationship indicates that the base temperature and $\mathrm{Tt}$ requirements for each development phase can be calculated from the least squares regression coefficients where:

Rate $=b_{0}+b_{1} x$

Equation 1

The coefficients can then be used to calculate $\mathrm{T}_{\mathrm{b}}\left({ }^{\circ} \mathrm{C}\right)$ and $\mathrm{Tt}\left({ }^{\circ} \mathrm{Cd}\right)$ as:

$\mathrm{T}_{\mathrm{b}}=-\mathrm{b}_{\mathrm{o}} / \mathrm{b}_{1}$

Equation 2

and

$\mathrm{Tt}=1 / \mathrm{b}_{1}$

Equation 3

Phyllochron was calculated as the Tt interval between the appearance of successive MS leaves from the first trifoliate leaf (MS leaf two) to the final MS leaf counted (MS leaf four or five in white and subterranean clovers, respectively).

\section{Results}

\section{Leaf appearance}

The sequence of leaf appearance was consistent across treatments but differed for white and subterranean clovers (Figure 1). For white clover, the first leaf produced by a stolon was leaf number four, and this was produced at approximately the same time as leaf number five (MS leaf four). However, in subterranean clover, the first leaf produced by a runner was leaf number five, which appeared at approximately the same time as leaf number six (MS leaf five), regardless of cultivar. Notable was that the stolon of 'Demand' white clover was initiated in the axil of the spade leaf(MS leaf one), whereas the runner of subterranean clover was initiated in the axil of the first trifoliate leaf (MS leaf two) for all cultivars.

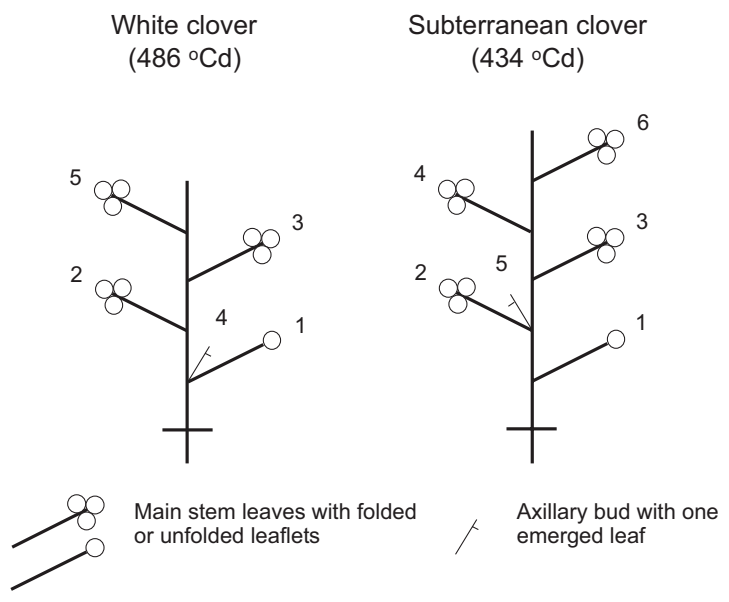

Figure 1 Stylised diagrams illustrating the development of seedlings of white and subterranean clovers after $486{ }^{\circ} \mathrm{Cd}$ and $434{ }^{\circ} \mathrm{Cd}$, respectively. During the period of growth, internodes on the main stem and stolons or runners (axillary buds) remain short.

The appearance of the first trifoliate leaf of these legumes followed a similar pattern regardless of species or cultivar. In all cases, the greatest number of days to appearance of the first trifoliate leaf was required at the lowest mean temperature. For example, all of the subterranean clover cultivars - as shown for 'Denmark' in Figure 2a-required less than 40 days to produce their first trifoliate leaf from SD4 when the mean temperature was $7.2^{\circ} \mathrm{C}$. However, for 
the same sowing date, 'Demand' white clover required 75 days to produce its first trifoliate leaf over a period when it experienced a mean temperature of $5.4{ }^{\circ} \mathrm{C}$ (Figure 2a). The number of days to the appearance of the first trifoliate leaf then declined exponentially to approximately 10 days for subterranean and 15 days for white clover as temperature increased to a mean of $23.5^{\circ} \mathrm{C}$. This led to a linear increase $\left(\mathrm{R}^{2}>0.88\right)$ in leaf appearance rate - as shown for 'Denmark' and 'Demand' in Figure $2 \mathrm{~b}$ - which enabled $\mathrm{T}_{\mathrm{b}}$ and $\mathrm{Tt}$ to be estimated (Table 2).
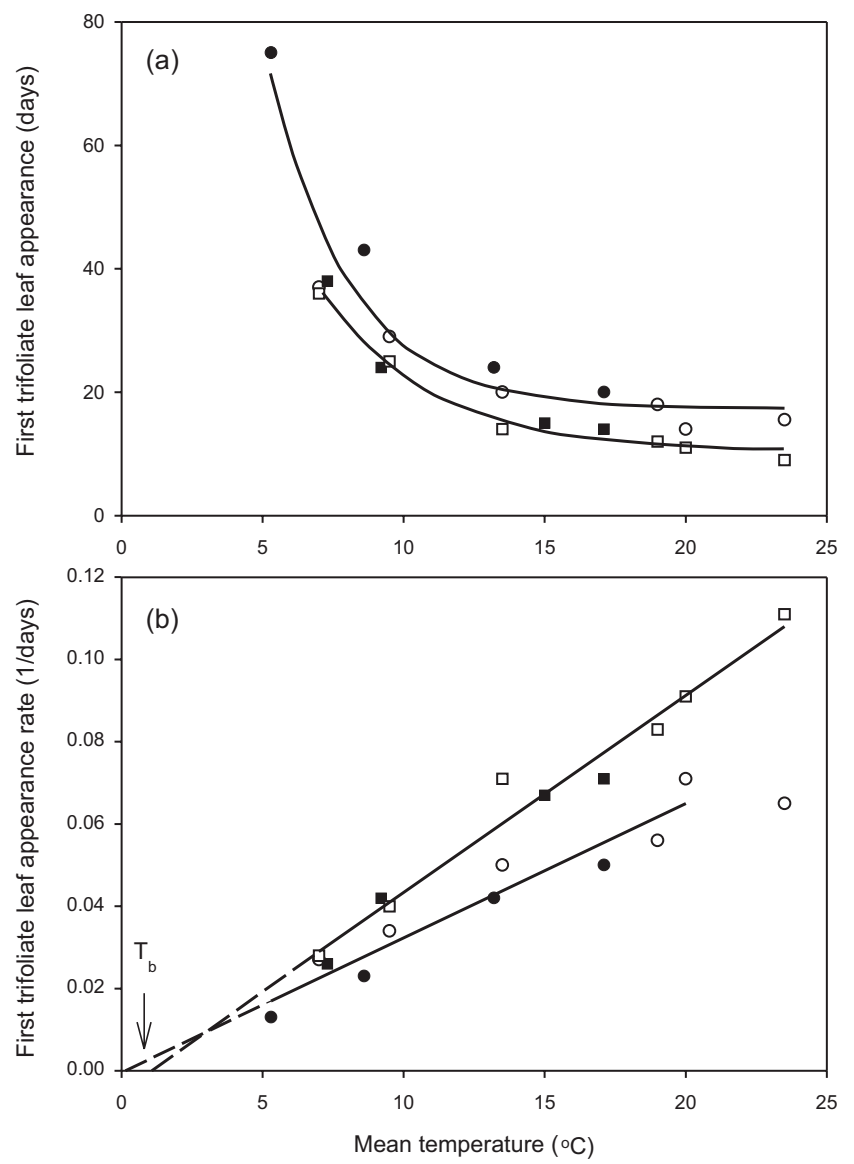

Figure 2 (a) Number of days to the appearance of the first trifoliate leaf and (b) first trifoliate leaf appearance rate of 'Demand' white $(\bullet)$ and 'Denmark' subterranean (ם) clovers grown under controlled environment (open symbols) and field (closed symbols) conditions at different temperatures. temperature were performed with the $\mathrm{T}_{\mathrm{b}}$ set at $0{ }^{\circ} \mathrm{C}$ (Moot et al. 2000). This enabled the Tt requirement ( \pm s.e.) for first trifoliate leaf appearance to be estimated at $230 \pm 20.0^{\circ} \mathrm{Cd}$ for all subterranean clover cultivars, compared with $309 \pm 10.0^{\circ} \mathrm{Cd}$ for 'Demand' white clover (Table 2).

The pattern of leaf appearance showed a distinct split at leaf number five and six for white and subterranean clovers, respectively, when the number of MS leaves continued to increase linearly but the total number of leaves increased exponentially. This is

Table 2 Base temperature $\left(T_{b}\right)$ and thermal time $(\mathrm{Tt})$ requirements for the appearance of the first trifoliate leaf for 'Demand' white clover and five subterranean clover cultivars grown in controlled environment and field experiments.

\begin{tabular}{lcccc}
\hline Cultivar & $\begin{array}{c}\mathrm{T}_{\mathrm{b}} \\
\left({ }^{\circ} \mathrm{C}\right)\end{array}$ & $\begin{array}{c}\mathrm{Tt} \\
\left({ }^{\circ} \mathrm{Cd}\right)\end{array}$ & $\begin{array}{c}\mathrm{R}^{2} \\
(\%)\end{array}$ & $\begin{array}{c}\mathrm{Tt} \\
\left({ }^{\circ} \mathrm{Cd}\right) \\
\left(\mathrm{T}_{\mathrm{b}}=0{ }^{\circ} \mathrm{C}\right)^{1}\end{array}$ \\
\hline Demand & 0.1 & 306 & 91 & 309 \\
Campeda & 1.6 & 194 & 96 & 216 \\
Denmark & 1.1 & 207 & 97 & 222 \\
Goulburn & -0.1 & 231 & 87 & 230 \\
Leura & 1.0 & 235 & 94 & 251 \\
Woogenellup & 0.1 & 234 & 97 & 234
\end{tabular}

$\mathrm{R}^{2}=$ coefficient of determination.

${ }^{1}$ Regression analysis with fixed $\mathrm{T}_{\mathrm{b}}=0{ }^{\circ} \mathrm{C}$.

shown for 'Demand' and 'Denmark' in Figure 3. The number of days required to reach this point decreased exponentially with increasing temperature, and linear regressions $\left(\mathrm{R}^{2}=0.84\right)$ between stolon or runner initiation rate and temperature enabled $\mathrm{T}_{\mathrm{b}}$ and $\mathrm{Tt}$ to be estimated (Table 3 ). Using a common $\mathrm{T}_{\mathrm{b}}$ of $0{ }^{\circ} \mathrm{C}$, runners of subterranean clover initially appeared after $434 \pm 35.0{ }^{\circ} \mathrm{Cd}$, compared with $486 \pm 10.0^{\circ} \mathrm{Cd}$ for stolons of white clover. From these data (Tables 2 and 3), the

To enable direct comparison of the Tt requirements for leaf appearance within and between species, additional regression analyses of rate against phyllochron $\left({ }^{\circ} \mathrm{Cd} / \mathrm{leaf}\right)$ for the MS leaves of subterranean clover was calculated as $68 \pm 6.5^{\circ} \mathrm{Cd}$ compared with $89 \pm 5.4^{\circ} \mathrm{Cd}$ for the MS leaves of white clover (Table 3 ). 


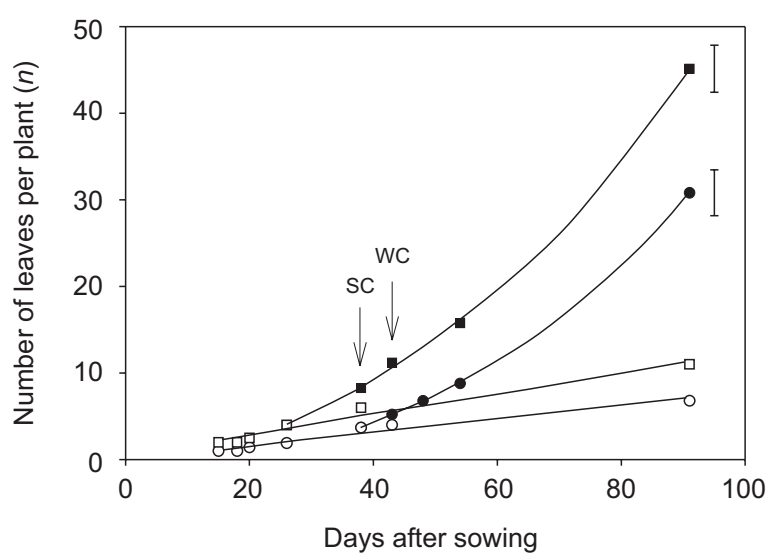

Figure 3 Number of total (closed symbols) and main stem (open symbols) leaves of 'Demand'

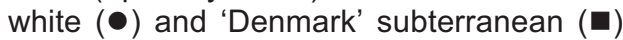
clovers plotted against days after sowing in the field on 21 March 2003 at Lincoln University, Canterbury. Arrows indicate the initiation of stolon or runner development (axillary buds) for white (WC) and subterranean (SC) clovers, respectively. Bars represent standard error for final total leaf number.

Table 3 Base temperature $\left(T_{b}\right)$ and thermal time $(T t)$ requirements for the initiation of stolons (or the five leaf stage) of 'Demand' white clover or runners (or the six leaf stage) of five subterranean clover cultivars grown in controlled environment and field experiments. The phyllochron is the thermal time interval between the appearance of successive leaves on the main stem (MS leaves).

\begin{tabular}{lccccc}
\hline & $\begin{array}{c}\mathrm{T}_{\mathrm{b}} \\
\left({ }^{\circ} \mathrm{C}\right)\end{array}$ & $\begin{array}{c}\mathrm{Tt} \\
\left({ }^{\circ} \mathrm{Cd}\right)\end{array}$ & $\begin{array}{c}\mathrm{R}^{2} \\
(\%)\end{array}$ & $\begin{array}{c}\mathrm{Tt} \\
\left({ }^{\circ} \mathrm{Cd}\right) \\
\left(\mathrm{T}_{\mathrm{b}}=0{ }^{\circ} \mathrm{C}\right)^{1}\end{array}$ & $\begin{array}{c}\text { Phyllochron } \\
\left({ }^{\circ} \mathrm{Cd} / \mathrm{leaf}\right) \\
\left(\mathrm{T}_{\mathrm{b}}=0{ }^{\circ} \mathrm{C}\right)\end{array}$ \\
\hline Demand & -0.8 & 509 & 84 & 486 & 89 \\
Campeda & -0.7 & 455 & 99 & 434 & 73 \\
Denmark & -0.2 & 426 & 96 & 422 & 67 \\
Goulburn & -2.5 & 504 & 90 & 435 & 68 \\
Leura & -1.3 & 494 & 96 & 456 & 68 \\
Woogenellup & -0.7 & 442 & 95 & 423 & 63
\end{tabular}

$\mathrm{R}^{2}=$ coefficient of determination.

${ }^{1}$ Regression analysis with fixed $\mathrm{T}_{\mathrm{b}}=0{ }^{\circ} \mathrm{C}$.

${ }^{2}$ Phyllochron was calculated from the first trifoliate leaf (MS leaf two) to four or five MS leaves of white and subterranean clovers, respectively.

\section{Dry matter production}

'Denmark' and 'Woogenellup' subterranean clovers are used as examples of the effect of sowing date on DM production for the five cultivars grown in the field experiment. By midSeptember, subterranean clover that germinated on 7 March (SD1) had produced approximately $7000 \mathrm{~kg} \mathrm{DM} / \mathrm{ha}$, while subterranean clover that germinated on 7 May (SD4) had produced only about one quarter of this yield at approximately $1800 \mathrm{~kg} \mathrm{DM} / \mathrm{ha}$. Thus, subterranean clover that germinated on 7 March produced $44 \mathrm{~kg}$ $\mathrm{DM} /$ ha/day for 158 days compared with $(\mathrm{P}<0.05)$ $15 \mathrm{~kg} \mathrm{DM} / \mathrm{ha} /$ day for 120 days from that which germinated on 7 May.

\section{Discussion}

The consistency of the results from both the controlled environment and field experiments showed that thermal time was the main determinant of first trifoliate leaf appearance in subterranean $\left(230^{\circ} \mathrm{Cd}\right)$ and white $\left(309^{\circ} \mathrm{Cd}\right)$ clovers (Table 2). The phyllochron for white clover (Table 2) was similar to that reported by Black et al. (2002), who indicated species differences contributed to seedling competitiveness and survival at establishment. The validity of using Tt to quantify seedling development is supported by the consistency of results from controlled environments and the fluctuating diurnal temperature regimes in the field. Thus, the results should be transferable beyond the site or season of investigation. Importantly, the $\mathrm{Tt}$ required to reach the start of an exponential increase in the number of leaves per plant was consistent across treatments, which means that this key development stage (Black et al. 2002) can be estimated from soil temperature data at any site after the onset of autumn rainfall.

The present study included a simple 'finger and thumb' test to estimate whether the subterranean clover seedlings would tolerate grazing. There was minimal seedling failure at the six-leaf stage, which suggests root and shoot growth were adequate to sustain grazing. However, this test also highlighted several complicating factors. Firstly, the prostrate growth habit of the subterranean subspecies made them more tolerant of grazing at juvenile growth stages than the more erect yanninicum subspecies. Secondly, where very high $\left(\sim 1000 / \mathrm{m}^{2}\right)$ populations of 
seedlings were established, the plants remained susceptible to grazing past the six leaf stage, as even the subterraneum subspecies retained an erect, etiolated growth habit under these conditions. Presumably the low light conditions within the dense sward were responsible. Thirdly, soil type had a marked effect on the ease with which seedlings could be pulled out of the soil by the test. Seedlings grown in loose friable potting mix were much more easily removed at this stage of development than those growing in a silt loam soil in the field. This may have practical implications for the time of grazing in areas such as the coastal sand country in the Manawatu, where subterranean clover is grown on very loose, easily eroded soils composed mainly of sand. However, we concede that these results are preliminary and that experiments should have begun earlier to identify the earliest possible time of success.

Thomas (2003) provides indirect evidence for the likely tolerance to grazing or otherwise of subterranean clover seedlings. He provided three diagrams of developing seedlings. The first seedling, with cotyledons only, and the second, with a total of two leaves, both appear to be susceptible to grazing because the cotyledons are clearly elevated above the soil. At these stages grazing would probably remove all potential growing points. The third diagram shows that by the time four leaves are present the hypocotyl has drawn the base of the cotyledons below soil level, and the axillary buds of the spade and first trifoliate leaf to approximately soil level. In this position, the growing points are unlikely to be removed by grazing unless the whole seedling is pulled out of the ground. On this basis, and considering the reservations discussed previously, the $\mathrm{Tt}$ requirement for the development of six leaves (including the spade leaf) presents a simple and repeatable criterion for the timing of first grazing of subterranean clover seedlings.

All of the five subterranean clover cultivars examined in the present study produced six leaves after approximately $434{ }^{\circ} \mathrm{Cd}$ from germination (Table 3 ). In areas of New Zealand where subterranean clover is grown, the timing of autumn rainfall required to allow germination of the seed is extremely variable, and may range from February to May. Table 4 lists the theoretical chronological time to safe grazing of subterranean clover, assuming rain arrives on the first day of each month for a range of sites in New Zealand. In a mild area, like Napier, only 23 days are required following a 1 February rain, but this extends to 39 days for 1 May. In contrast, in cooler areas like Alexandra, following a 1 February rainfall, 26 days are required before grazing can commence, while seeds that germinate on 1 May are vulnerable to frost heave due to their slow growth and development. If they survive, they would require 102 days before reaching the six-leaf stage.

Table 4 Chronological time (days) to safe grazing of subterranean clover at several New Zealand sites with varying dates of opening autumn rains (actual days calculated from NIWA meteorological data summaries, and Lincoln data from Broadfields Meteorological station, using a base temperature of $0^{\circ} \mathrm{C}$ ).

\begin{tabular}{lcccc}
\hline \multicolumn{5}{c}{ Time of Opening Rain } \\
\hline Location & February 1 & March 1 & April 1 & May 1 \\
\hline Lincoln & 26 & 29 & 37 & 53 \\
Alexandra & 26 & 30 & 46 & 102 \\
Blenheim & 25 & 27 & 34 & 47 \\
Napier & 23 & 25 & 30 & 39 \\
\hline
\end{tabular}

The present study also showed that subterranean clover that germinated in March produced substantially more herbage than that which germinated in early May. The cumulative yields were approximately 7000 and $1800 \mathrm{~kg} \mathrm{DM} /$ ha, respectively, by mid-September. Silsbury \& Fukai (1977) also found autumn-winter yield was maximised by early germination. Some care must be taken in extrapolating the yields reported in the present study to the practical farming situation. Firstly, the experiment was conducted on a deep, moisture-retaining soil usually used for intensive cropping, and where white clover is the normal pasture legume grown, especially where irrigation is available. On shallow, low fertility soils, yields have been approximately half those reported here (Smetham \& Jack 1995; Scott 1971; Ledgard et al. 1987). Secondly, the swards comprised of pure subterranean or white clover, and were hand weeded as required. The pros and cons of growing subterranean clover alone or in a mixture with grasses have been well reviewed by Smetham (2003). He concluded that under New Zealand conditions, subterranean clover is usually grown with a native or introduced grass to provide feed longer into summer and help reduce ingress of annual weeds, despite the reported yield advantage of clover monocultures. 
Resident grasses are always present in hill country pastures.

Subterranean clover seedlings are sensitive to grass dominance and shading (McGuire 1983). On nonarable country, grass competition can only be reduced by grazing management, but a balance needs to be reached between under- and overgrazing, especially by sheep, which can lead to extensive areas of bare ground and compacted soil (Costello \& Costello 2003). Where the paddock can be cultivated, the production of 'top-worked subterranean clover greenfeed' is recommended (Calder 1954). This practice consists of light cultivation with a grubber or discs followed by harrowing and perhaps rolling. Fertiliser may be incorporated into the soil at the same time. When autumn rains arrive, the resultant establishment and growth of subterranean clover can be significant. Top working has the potential to turn a 'false break' into a successful establishment by greatly reducing the competition from other species, all of which can be considered weeds in this situation.

\section{Conclusions}

This study provided quantifiable criteria for the timing of first grazing of subterranean clover seedlings. Specific conclusions were:

1. Leaf appearance rate in subterranean clover is determined by $\mathrm{Tt}$, with a thermal time requirement for first trifoliate leaf appearance of $230^{\circ} \mathrm{Cd}$, and a phyllochron of $68{ }^{\circ} \mathrm{Cd}$, measured across five cultivars.

2. Subterranean clover seedlings are likely to survive grazing after they have produced six leaves. The chronological time (days) taken to reach this stage depends on district and timing of autumn rainfall, but is constant in $\mathrm{Tt}$ at $434^{\circ} \mathrm{Cd}$.

3. Subterranean clover that germinated on 7 March produced three times the amount of DM than that which germinated on 7 May. This increase in DM production was out of proportion to the chronological time involved, because this process is driven by both thermal time and light interception.

\section{ACKNOWLEDGEMENTS}

The authors acknowledge Dr Keith Pollock for assistance with monitoring temperatures, Stuart Larsen for assistance with the controlled environment cabinets.

\section{REFERENCES}

Black, A.D.; Moot, D.R.; Lucas; R.J. 2002. Seedling development and growth of white clover, caucasian clover and perennial ryegrass grown in field and controlled environments. Proceedings of the New Zealand Grassland Association 64: 197-204.

Calder, J.W. 1954. Subterranean clover pastures for light land. Agricultural Bulletin 301. Canterbury Chamber of Commerce, Christchurch, New Zealand.

Carter, E.D.; Cochrane, M.J. 1985. The poor subterranean clover status of dairy pastures in the Adelaide Hills. pp. 217-219. In: Proceedings of the $3^{\text {rd }}$ Australian Agronomy Conference, University of Tasmania, Hobart Jan/Feb 1985. Ed. Yates, J.J. Australian Society of Agronomy, Parkdale, Victoria.

Costello, T.J.; Costello, A.E. 2003. Subterranean clover in North Canterbury sheep pastures. In: Moot, D.J. (ed.) Legumes for dryland pastures. Proceedings of a New Zealand Grassland Association symposium, Lincoln University, 1819 November 2003. Grasslands Research and Practice Series; no. 11: 187-190.

Dear, B.S; Gregan, P.D.; Murray,G.M. 1993. Comparison of the performance of subterranean clover cultivars in southern New South Wales. I. Persistence productivity and seed yields. Australian Journal of Agricultural Research 33: 581-590.

Jamieson, P.D.; Brooking, I.R.; Porter, J.R.; Wilson, D.R. 1995. Prediction of leaf appearance in wheat: a question of temperature. Field Crops Research 41:35-44.

Ledgard, S.F.; Brier, G.J.; Littler, R.A. 1987. Legume production and nitrogen fixation in hill pasture communities. New Zealand Journal of Agricultural Research 30: 413-424.

McGuire, W.S. 1985. Subterranean clover. pp. 515534. Clover Science and Technology, Agronomy Monograph. No .25.

Moot, D.J.; Scott, W.R.; Roy, A.M.; Nicholls, A.C. 2000. Base temperature and thermal time requirements for germination and emergence of temperate pasture species. New Zealand Journal of Agricultural Research 43: 15-26.

Peacock, J.M. 1975. Temperature and the growth of Lolium perenne. 2. The site of temperature perception. Journal of Applied Ecology 12: 115123.

Rossiter, R.C. 1966. The success or failure of strains of Trifolium subterraneum in a Mediterranean environment. Australian Journal of Agricultural 
Research 17: 425-446.

Scott, W.R. 1971. An agronomic evaluation of subterranean clover cultivars. Proceedings of the New Zealand Grassland Association 33: 134-140.

Silsbury, J.H.; Fukai, S. 1977. Effects of sowing time and sowing density on the growth of subterranean clover at Adelaide. Australian Journal of Agricultural Research 28: 427-440.

Smetham, M.L. 2003. A review of subterranean clover (Trifolium subterraneum L.): Its ecology and use as a pasture legume in Australasia. Advances in Agronomy 79: 303-349.
Smetham, M.L.; Jack, D.W. 1995. Herbage production under grazing of some subterranean clover lines compared with lucerne. Proceedings of the Agronomy Society of New Zealand 25: 69-76.

Thomas, R.G. 2003. Comparative growth forms of dryland forage legumes. In: Moot, D.J. (ed.) Legumes for dryland pastures. Proceedings of a New Zealand Grassland Association symposium, Lincoln University, 18-19 November 2003. Grasslands Research and Practice Series; no. 11: 19-25. 